\title{
Multimedia Games and Vocabulary Learning
}

\author{
Samira Ghanbaran \\ Department of English Language and Literature, University of Isfahan, Iran \\ Saeed Ketabi \\ Department of English Language and Literature, University of Isfahan, Iran
}

\begin{abstract}
Vocabulary has been established as the primary way towards learning a new language (Carter, 2001). With the advent of the computer technology, various degrees of change has been felt in different areas of education. As for language learning, this intervention has been very palpable. This study is an attempt to look at the reported effect of multimedia games on language learning in the related literature. To this end, first, concepts of incidental and intentional vocabulary learning are introduced. In the next step, some aspects of vocabulary (learning) are dealt with concisely and finally multimedia games and their effect on vocabulary learning are briefly discussed.
\end{abstract}

Index Terms - multimedia games, vocabulary, incidental learning, intentional learning

\section{INTRODUCTION}

Knowledge of vocabulary plays an important role in learning L2 skills. Frequent studies have been conducted by different researchers comparing the effect of different vocabulary presentation strategies (Huckin, Haynes \& Coady, 1993; Hatch \& Brown, 1995; Coady \& Huckin, 1997; Atkins, 1998; Read, 2000; Nation, 2001). In the following sections, first, some preliminary notions are introduced and then the effect of multimedia games on vocabulary learning is discussed briefly.

\section{INCIDENTAL LEARNING VERSUS INTENTIONAL LEARNING}

Different lines of investigation focusing on incidental and intentional learning have appeared in psychology since the beginning of the twentieth century (Eysenck, 1982; McLaughlin, 1965; postman, 1964). As a result, hundreds of experiments have been conducted in this regard (Smith, 1998). In the following two sections, the notions of incidental and intentional learning are introduced and some related studies are reviewed.

\section{A. Incidental Learning}

According to Kerka (2000), incidental learning is unintentional or unplanned learning which involves no deliberate intention to learn or to analyze language, an explanation which might include implicit learning in the psychological sense. Huckin and Coady (1999) defined incidental vocabulary acquisition as learning new words through some communicative activities while focus is on meaning, such as interaction, reading or listening. According to this definition,learning takes place through 'multiple exposures to a word in different contexts' (Huckin\&Coady, 1999, p. 185). Foreign language learners' mechanism for learning new words has generally been assumed to be much like small children as they acquire the vocabulary of their L1 through picking up most of their new words and expressions incidentally (Nation \& Waring 1997). As a result, the best way of improving vocabulary learning is considered to be through inferring word meanings from the meanings of constituent morphemes and from contexts.In cases of not being able to infer the meaning, students have often been supposed to simply toleratethe vagueness and wait forricher contexts to clarify the meaning for them. The non-recurrence of an un-guessed wordhas simply meant that the word is too infrequent to be worth learning anyway.

Schmidt (1994) considered incidental learning as referring to learning to learn one thing not as a primary object or without an intention to learn.Laufer (2005)rejected any focus on forms in vocabulary instruction and, in other words, rejectedexplicit (or targeted orgenuine) form-focused vocabulary teaching:

[...] on encountering an unfamiliar word, the learner notices it as a word s/he does not know, decides to infer its meaning from context by using a variety of linguistic and non-linguistic clues, has a good chance of making a correct guess, and may consequently retain partial or precise meaning of the word. If the word is not remembered after the learner's first exposure to it, or if only partial information about the word has been acquired, additional encounters with the same word will increase the probability of retaining it and expanding its knowledge. Even if very few words are retained after one communicative activity or text, the cumulative gains over time may be quite remarkable if the learner reads regularly (p. 226).

It was believed thatexplicit vocabulary teaching was a waste of time because 'few words are retained from those which are "learned" or "taught" by direct instruction' (Harris \&Snow, 2004, p. 55), and that 'most L2 vocabulary is learned incidentally, much of it from oral input' (R. Ellis, 1994, p. 24). 


\section{B. Intentional Learning}

Intentional learning is often defined in contrast with incidental learning. According to Hulstijn (2001), intentional vocabulary learning is an activity which is intended for committing lexical information (sound, spelling, meaning, and grammar rules) to memory. Wesche and Paribakht (1998) define intentional vocabulary learning as learning new words while the learner intends to do so,such as when a learner completes activities in a workbook or studies a list of target words while they intend to learn a set of new target words.Intentional and incidental learning are set apartconsidering the use of instructions that might make explicit the existence of a later retention test (Eysenck 1982).Nevertheless, a great deal of vocabulary learningmay be a combination of both incidental and intentional learning (Kennedy, 2003).

\section{SigNifiCANCE OF VocABUlaRY}

The significance of vocabulary acquisition in learning another language is illustratedby Wilkins (1972) as "Without grammar, little can be conveyed, without vocabulary, nothing can be conveyed" (p. 111). Formerly, lexical aspects were subordinated and undervalued to the study of grammatical structures (Nation, 1998).However, today, vocabulary is considered as the primary way towards learning a new language (Carter, 2001).

Many second language professionals regard vocabulary as the first and foremost challenge L2 learners face as they engage in reading texts or listening in the target language (Folse et al., 2005; Grabe\&Stoller, 1997; Hulstijn, 2001; Nation, 1990, 2001; Read, 2004). Lewis (2000) considered acquiring a sufficiently large vocabulary the most important task language learners are supposed to deal with.Decarrico (2001) claims that "vocabulary learning is central to first and second language acquisition and specialists now emphasize the need for a systematic and principled approach to vocabulary by both teachers and learners" (p. 285). As a result, vocabularylearningis often perceived to be "of critical importance to the typical language learner" (Zimmerman, 2001, p. 5).Schmitt (2008) also considers vocabulary as "an essential part of mastering a second language" (p. 329).

\section{DifFerent Aspects of Vocabulary KnOWLedGe}

Vocabulary knowledge is considered to have two primary dimensions, that is, depth and breadth (Qian, 1999). Depth of vocabulary knowledge consists of such types of knowledge as pronunciation, stylistic features, spelling, antonymy, synonymy, hyponymy and collocational meaning (Nation, 1990; Read, 2000; Richards, 1976). According Qian (1999) depth of vocabulary knowledge can include components such as frequency, spelling, register, collocational properties, pronunciation, and syntactic, morphological, andmeaning. Qian argues thatthese components are interconnected both structurally and functionally.Breadth of vocabulary, on the other hand, pertains to the number of words that language learners have partial or complete knowledge of (Nation, 2001).

Chapelle (1998) believed that a vocabulary definition should consist of four aspects: (a) knowledge of word properties, (b) vocabulary size, (c) processes of lexical access, and (d) lexicon organization. Henriksen (1999) also suggested three vocabulary dimensions: (a) a "depth of knowledge" dimension, (b) a "receptive-productive" dimension, and (c) a "partial-precise knowledge" dimension. Qian's (2002), considering the collective strength of earlier models of vocabulary knowledge, proposed a framework for vocabulary knowledge which consisted of four inherently connected dimensions: (a) automaticity of receptive-productive knowledge, (b) lexical organization, (c) depth of vocabulary knowledge, and (d)vocabulary size.

\section{STUDIES ON INCIDENTAL VOCABULARY ACQUISITION}

Over the last two decades, a large number of empirical studies have been conducted on vocabulary acquisition or learning based ondifferent themes:the relationship between language proficiency andvocabulary knowledge, particularly with regard to reading (Hazenberg \& Hulstijn, 1996; Hu \& Nation, 2000); the construct of vocabulary knowledge, e.g. the distinction between varioussorts of vocabulary knowledge; vocabulary learning and word frequency, e.g. the benefit and/or cost of learning specialized, infrequent and frequent words (Coxhead, 2000; Nation 2001); productive and receptive knowledge, and between use and knowledge (Henriksen, 1999; Read \& Chapelle, 2001);interactive tasks (Ellis, Tanaka \& Yamazaki, 1994); intentional versus incidental learning (Ellis \& He 1999; Horst, Cobb \& Meara, 1998; Kelly, 1986); vocabulary development patterns over time (Laufer 1998; Palmberg, 1987); the effect of tasks on learning, e.g. task induced involvement (Laufer \& Hulstijn, 2001); implicit versus explicit learning (N. Ellis, 1994); vocabulary knowledgetesting: depth andsize, productive and receptive (Bogaards, 2000; Laufer \& Nation, 1995, 1999; Read, 1993, 2000); the use of different types of dictionaries, electronic and paper (Bogaards, 1991; Chun \&Plass, 1996; Knight 1994); learners' strategies for comprehending and learning new words (Cohen \& Aphek, 1981; Sanaoui, 1995); and learning new meanings of already known words versus learning new words (Bogaards, 2001).

Prince (1996) compared L2 word learning in one or two sentences and L1 and L2 paired-associate learning, trying to compare the benefits and drawbacks of incidental vocabulary learning from context and intentional learning through translated words into L1 equivalents. The results of the study were in favor of paired-associate learningin terms of quantity but the learners' ability in supplying the words in appropriate sentences declined.Laufer and Shmueli (1997) made a comparison between four learning conditions: (a) learning all the words, provided with L2 or L1 glosses in the 
left margin, in a long text, and (b) learning all the target words in an "elaborated" text with the same glosses as in(a), (c) learning an L2 word with L2 and L1 glosses and the target word embedded in a sentence (d) learning an L2 word with L2 or L1 glosses. The target words in the elaborated text were provided with a short definition just after each word. The results revealed that conditions (c) and (d) lead to meaningfullyhigherscores than (a) and (b).

Webb (2007) compared two different kinds of learning: a) paired-associate learning b) context learning, including an L1 equivalent, an artificial target word, and an example sentence. He tried to make use of the different aspects of participants'knowledge of vocabulary obtainedthrough these two conditions through conducting 10 different productive and receptive tests. The results of ten tests between the two conditions did not indicate any significant difference. The results also proved that the only aspect of vocabulary knowledge obtained by participants was the meaning of words from context. However, list learning or paired-associate can be effectivetechniques for learning a large number of words in a short period of time (Fitzpatrick, Al-Qarni, Meara, 2008; Milton, 2009).

Another way of teaching new words is through accompanying them with other words in teaching.It is widely accepted that a large number of formulaic sequencesacting as a single unite in Englishdo exist in our lexicon repertoire and that "they make up a large proportion of any discourse" (Schmitt \& Carter, 2004, 1). These combinations have been named in various ways, such as exemplars, collocations, chunks, lexical units ormultiword units. Wray (2002) called them formulaic sequences and defined them as "a sequence, continuous or discontinuous, of words or other elements, which is, or appears to be, prefabricated: that is, stored and retrieved whole from memory at the time of use, rather than being subject to generation or analysis by the language grammar" (p. 9). Since the 1990s, the significance of these collocationsor formulaic sequences has been highlighted by many vocabulary researchers and their integration into second language courses has been emphasized (Lewis, 1993, 2000; McCarthy, 1990; Nattinger \& DeCarrico, 1992; Simpsom-Vlach \& Ellis, 2010; Sinclair, 1991). Mastery of formulaic sequences, according to some studies, can not only be used in distinguishing native speakers from non-native speakers (Durrant\& Schmitt, 2009; Siyanova \& Schmitt, 2007) but also lower level from higher level second language learners (Hsu, 2007). It has been widely accepted in the applied field of language teaching that most of L2 vocabulary acquisition takes place as a by-product of reading and listening while focusing on meaning instead of form (e.g. Jenkins, Stein \& Wysocki, 1984; Nagy \& Anderson, 1984; Nagy, Herman \& Anderson, 1985). Many factors have been shown to affect vocabulary acquisition such as inferencing and/or glossing (Cobb \& Horst, 2001; Hulstijn, 1992), new word density (Holley, 1973), reading purpose (Swanborn \& Glopper, 2002) and new word frequency (Rott, 1999).

Cognitive psychologists believe that the more elaborate the processing of new lexical information, the better the retention (e.g. Eysenck, 1982).In other words,retentionimproves as a result of attention to pronunciation, orthography, the words meanings, grammatical category along with the association made between other words andthe word. This idea has been found applicable to both intentional and incidental learning (Paribakht \& Wesche, 1999; Huckin \& Coady, 1999). For instance, the results of a study conducted by Joe (1995) on vocabulary development of an adult learner in a read and retell taskshowed that task requirements considerably increased incidental vocabulary learning.Newton (1995) also reported similar results in his examination of the relationship in a task-based interactionstudy.

Several factors have been identified as effecting the extent of incidental word learning in reading such as reading skill,readers' age,students' knowledge oftopic and their acquaintance with the represented concepts through the new words, a number of text and word properties and inferencing (Swanborn \& de Glopper, 1999). Swanborn and de Glopper (2002) believed that unknown word meanings are acquired even though the readers do not intend to learn the unknown vocabulary. Close associations have also been made between lexical inferencing and incidental vocabulary learning (Huckin \& Coady, 1999). Wesche and Paribakht (1998) also argue thatmuch if not mostL1 and L2lexical developmentseems to take placewhile learners attempt to comprehend.

The acquisition of the meaning of new words an extensive readingby-producthas been studied in terms of issuessuch asprocedures and resources employed in inferencing. The obtained results of the studies dealing with the issue demonstrated that sentence contexts as well as definitions contributed to vocabulary learning. The results of the study by Nist and Olejnik (1995) support this claim since it demonstrates that as learners encounter a word in context and after that go through its definition, their performance on multiple-choice questions could improve.

Depending merely on extensive reading- particularly in L2 context -has been shown to lead to low degrees of vocabulary acquisition, showing the insufficiency of this approach towardssecond language learners (Rosszell, 2007; Waring \& Takaki, 2003; Zahar, Cobb \&Spada, 2001). The results of the study by Saragi, Nation, and Meister's (1978) showed that a minimum of 10 exposuresin a text were required for Ll learners who were learning pseudo-words periodicallyto acquire words. The results of a study by Nagy, Herman, and Anderson (1985) demonstrated that the probability of acquiring a word as a result of exposure to context just once is between .10 and .15and, according to a follow-up study, it can be lowered as much as .05. Nation (1990) surveyed this and other studies and showed that in order for full acquisition to occur 5 to 16 exposures were required. On the other hand, some researchers have argued that incidental vocabulary learning can occur through two exposures (e.g. Rott, 1999). The results of the study conducted by Nagy, Herman and Anderson (1985) showed that the rate of vocabulary learning 15 minutes after reading was 1 in 10. The rate reported by Nagy, Anderson, Herman (1987) in their study of vocabulary learning six days after reading was 1 in 20. The results of a meta-analysis of 20 studies conducted on native speaker participants 
demonstratedan average probability of $15 \%$, supporting the idea that more incidental learning can occur as a result of smaller proportions of unknown words (Swanborn \& de Glopper, 1999).

Glossing,as an input modification strategies, has also been consideredas very effective for incidental words acquisition. For instance, it has been shown that reading passages accompanied by vocabulary glosses contribute to new wordsincidental learning (Jacobs, 1994; Ko, 1995; Hulstijn, Hollander, \& Greidanus, 1996). It has also been demonstrated that multiple-choice glosses in comparison to presenting the meaning or providing words with no glosses lead to higher vocabulary scores (Hulstijn, 1992). And finally, Yoshii (2006) made a comparison betweenincidental vocabulary learning with L1 and L2 glosses. The obtained results of the investigation indicated that nomeaningful difference existed between the use of native or target language glosses in terms of vocabulary acquisition.

Incidental vocabulary learning has also been dealt withregardingtext familiarity as an influential factor. It has been shown that incidental learning of nonsense words can be facilitated through cultural background knowledge and topic familiarity (Pulido, 2004, 2007). A number of studies have been conducted wherethe participants read authentic texts (Ferris, 1988; Dupuy \& Krashen, 1993). The result of a study conducted by Zahar et al. (2001) indicated that, on average, ESL students in Canada could learn the meaning of $22 \%$ of unknown words or 2.16 out of 10.34 words. A similar study conducted by Daskalovska (2010) also indicated that the EFL secondary school students learned the meaning of $25.16 \%$ of the words.

Some studies have tried to look at the acquisition of other dimensions of word knowledge than meaning (PellicerSánchez \& Schmitt, 2010; Tavakoli \& Gerami, 2012). The results of a case study conducted by Pigada and Schmitt (2006) in order to see the effect of reading extensivelyindicated an improvement in the spelling, meaning and grammatical characteristics knowledge. Webb (2007) also studied the effect of frequency on the acquisition of grammatical functions, form, meaning, orthography, association and syntax. The results of the investigation indicated that all aspects improved with an increase in the number of presentations.

\section{Multimedia Games and Vocabulary Development}

According to Nation (1990), in order to acquire vocabulary, students are to be challenged and focus their attention through new strategies. It is believed that games stimulate students and provide them with opportunity play an active role in their own learning (Claxton, 2008). Due to the ever-increasing variations of video games, the investigation of the relationship between the media and language acquisition has been problematic. Many genres of commercial (Wolf, 2001) and educational (i.e. "serious") games (Sawyer \& Smith, 2008) have been recognized. The games can be different in such aspects as theme, intended audience,, human-computer interface, graphical fidelity, hardware, and interaction between players.

One aspect of multimedia games is increasing motivation and fostering a deeper processing of vocabulary. The results of some studies have indicated that active participation in vocabulary games will lead to learning reinforcement (Baltra, 1990; Carrier, 1991; deHaan, 2005; Hubbard, 1991; Li \& Topolewski, 2002; Bell, 2005). The result of the study conducted by Yip and Kwan (2006) demonstrated that learning vocabulary through multimedia games led to a change in the attitude of learners towards language learning. Naderi (2002) investigated the effect of 20 language games on English learning improvement. The results of the study indicated the effectiveness ofgames in learning English in middle schools. Segers and Verhoeven (2003) conducted a study on 67 native and immigrant childrenin order to investigate vocabulary training through computers. The participants were in the first and second years of kindergarten in the Netherlands. Theyplayed computer vocabulary games twice a weekover 15 weeks. Each session took a period of 15 minutes. As a control group, 97 kindergartners went through the regular curriculum. The results of the curriculumindependent test conducted revealed the positive effect of computer training on vocabulary learning.

Marzano and Brown (2007) engaged in over 60 studiesconducted in order to investigate the effect of using games in the classroomon students' accomplishment. The results of the study indicated a 20 percentile increase in students' achievement. A number of studies have revealed that games can have positive effect on achievement, interest, task learning engagement and problem solving (Kim, Park, \& Baek, 2009; Tuzun et al., 2008; Wideman, et al. 2007; Oyen \& Bebko, 1996; Robertson \& Howell, 2008). The results of a study conducted on language learning of young learnersthrough computer games in Turkey by Turgut and Irgin (2009) revealed that the performance of young learners involved in playing online games was better in language skills, especially vocabulary skill.

Another related aspect is that, in the context of a game, vocabulary skill can be acquired without pressure (Kohl, 1981).Besides, games can provide language learners with a platform for practicing skills (Kohl, 1981). DeHaan (2005) conducted a study on Japanese (as a foreign language) students who played a baseball video game for a month period. In spite of anecdotal positive learning outcomes, the participant reported that he could not completely focus on the game and that he was distracted by listening to and reading the Japanese, a result in line with Brett's (2001) findings and Kalyuga, Chandler and Sweller's (1999) suggestions.

\section{CONCLUSION}

As the review of the related literature indicates, the studies on the effect of multimedia games on second language acquisition/learning are restricted. Considering the bewildering advancement rate of technology in various fields, 
including multimedia games, further research considering the effect of various facets of this technological development on different aspects of vocabulary acquisition/learning seems very promising.

\section{REFERENCES}

[1] Atkins, B. S. (1998). Using dictionaries: Studies of dictionary use by language learners and translators (Vol. 88). Germany: Max Niemeyer Verlag.

[2] Baltra, A. (1990). Language learning through computer adventure games. Simulation and Gaming Journal, $21,445-452$.

[3] Bell, N. D. (2005). Exploring L2 language play as an aid to SLL: A case study of humour in NS-NNS interaction. Applied Linguistics, 26(2), 192-218.

[4] Bogaards, P. (1991). Word frequency in the search strategies of French dictionary users. Lexicographica, 7, $202-212$.

[5] Bogaards, P. (2000). Testing L2 vocabulary knowledge at a high level: The case of the Euralex French Tests. Applied Linguistics, 21(4), 490-516.

[6] Bogaards, P. (2001). Lexical units and the learning of foreign language vocabulary. Studies in Second Language Acquisition, 23(3), 321-343.

[7] Brett, P. (2001). Too many media in my multimedia? A study of the effects of combinations of media on a recall task. Paper presented at Escuela Superior de Administracion y Direccion de Empresas, Barcelona, Spain.

[8] Carrier, M. (1991). Simulations in English language teaching: A cooperative approach. Simulation and Gaming Journal, 22(2), 224-33.

[9] Carter, R. (2001). Vocabulary. In R. Carter and D.Nunan (Eds.). The Cambridge Guide to Teaching English to Speakers of Other Languages (pp. 42-47). Cambridge: Cambridge University Press.

[10] Chapelle, C. (1998). Construct definition and validity inquiry in SLA research. In L. F. Bachman, Interfaces between second language acquisition and language testing research(p. 32-70). Germany: Ernst KlettSprachen.

[11] Chun, D. M., \&Plass, J. L. (1996). Effects of multimedia annotations on vocabulary acquisition. The modern language journal, 80(2), 183-198.

[12] Claxton, N. (2008). Deliberating across the curriculum: using deliberative techniques in the English as a foreign language classroom. New York, NY: IDEBATE Press.

[13] Coady, J., \&Huckin, T. (1997). Second language vocabulary acquisition. Cambridge: Cambridge University Press.

[14] Cobb, T., \& Horst, M. (2001). Growing Academic Vocabulary with a Collaborative On-Line Database. Retrieved from http://elc. polyu. edu. hk/conference//papers2001/cobb. htm on October 12, 2012.

[15] Cohen, A. D., \&Aphek, E. (1981). Easifying second language learning. Studies in second language acquisition, 3(02), $221-236$.

[16] Coxhead, A. (2000). A new academic word list. TESOL quarterly, 34(2), 213-238.

[17] Daskalovska, N. (2010). Acquiring vocabulary through reading: A replication of the Golden Fleece study. Current Trends in SLA Research and Language Teaching, 13, 314-319.

[18] Decarrico, J. S. (2001). Vocabulary learning and teaching. Teaching English as a second or foreign language, 3, $285-299$.

[19] deHaan, J. (2005). Learning language through video games: A theoretical framework, an analysis of game genres and questions for future research. In S. Schaffer \& M. Price (Eds.), Interactive Convergence: Critical Issues in Multimedia (vol. 10) (pp. 229239). Retrieved from http://www.inter-disciplinary.net/publishing/idp/eBooks/icindex.htm on November 12, 2012

[20] Dupuy, B., \&Krashen, S. D. (1993). Incidental Vocabulary Acquisition in French as a Foreign Language. Applied Language Learning, 4(1), 55-63.

[21] Durrant, P., \& Schmitt, N. (2009). To what extent do native and non-native writers make use of collocations?IRALInternational Review of Applied Linguistics in Language Teaching, 47(2), 157-177.

[22] Ellis, N. (1994). Consciousness in second language learning: Psychological perspectives on the role of conscious processes in vocabulary acquisition. Consciousness in second language learning, 11, 37-57.

[23] Ellis, R. (1994). The study of second language acquisition. UK: Oxford University Press.

[24] Ellis, R., \& He, X. (1999). The roles of modified input and output in the incidental acquisition of word meanings. Studies in Second Language Acquisition, 21(2), 285-301.

[25] Ellis, R., Tanaka, Y., \& Yamazaki, A. (1994). Classroom interaction, comprehension, and the acquisition of L2 word meanings. Language learning, 44(3), 449-491.

[26] Eysenck, M. W. (1982). Attention and arousal: Cognition and performance. New York, NY: Springer-Verlag.

[27] Ferris, D. (1988). Reading and second language vocabulary acquisition. Unpublished manuscript, Department of Linguistics, University of Southern California.

[28] Fitzpatrick, T., Al-Qarni, I., \&Meara, P. (2008). Intensive vocabulary learning: A case study. Language learning journal, 36(2), 239-248.

[29] Folse, K. S., Mitchell, D., Smith-Palinkas, B., \&Tortorella, D. M. (2005). Clear Grammar: Activities for Spoken and Written Communication. Mch: University of Michigan Press.

[30] Gee, J. P. (2007). Good Video Games Plus Good Learning (Vol. 27).UK: Peter Lang.

[31] Grabe, W. \&Stoller, F.L. (1997). Reading and vocabulary development in a second language: a case study. In Coady, J. \&Huckin, T. (Eds.), Second Language Vocabulary Acquisition (p. 98-122). UK: Cambridge University Press.

[32] Harris, V., \& Snow, D. (2004). Doing it for themselves: focus on learning strategies and vocabulary building. UK: CILT.

[33] Hatch, E., \& Brown, C. (1995). Vocabulary, semantics, and language education. New York, NY: Cambridge University Press.

[34] Hazenberg, S., \&Hulstun, J. H. (1996). Defining a minimal receptive second-language vocabulary for non-native university students: An empirical investigation. Applied linguistics, 17(2), 145-163.

[35] Henriksen, B. (1999). Three dimensions of vocabulary development. Studies in second language acquisition, 21(2), 303-317.

[36] Holley, F. M. (1973). A Study of Vocabulary Learning in Context: The Effect of New-Word Density in German Reading Materials*. Foreign Language Annals, 6(3), 339-347. 
[37] Holyoak, K. J. (1991). Problem solving. In D. N. Osherson, \& E. E. Smith (Eds.), Thinking. An invitation to cognitive science (pp. 117-146). Cambridge: The MIT Press.

[38] Horst, M., Cobb, T., \&Meara, P. (1998). Beyond the clockwork Orange: Acquiring second language vocabulary through reading. Reading in a foreign language, 11, 207-223.

[39] Hsu, J. Y. (2007). Lexical collocations and their relation to the online writing of Taiwanese college English majors and nonEnglish majors. Electronic Journal of foreign language teaching, 4(2), 192-209.

[40] Hu, M. H., \& Nation, P. (2000). Unknown vocabulary density and reading comprehension. Reading in a Foreign Language, 13(1), 403-430.

[41] Hubbard, P. (1991). Evaluating computer games for language learning. Simulation \& Gaming, 22(2), 220-223.

[42] Huckin, T., \&Coady, J. (1999). Incidental vocabulary acquisition in a second language. Studies in second language acquisition, 21(2), 181-193.

[43] Huckin, T., Haynes, M., \&Coady, J. (1993). Second langua reading and vocabulary learning. Norwood, N.J.: Albex Publishing Corporation.

[44] Hulstijn, J. H. (1992). Retention of inferred and given word meanings: Experiments in incidental learning. In P. J. L. Arnaud and $\mathrm{H}$. Bejoint, vocabulary and applied linguistics (p. 113-120). Hondon: Macmillian.

[45] Hulstijn, J. H. (2001). Intentional and incidental second language vocabulary learning: A reappraisal of elaboration, rehearsal and automaticity. In P. Robinson (Ed.), Cognition and second language instruction (pp. 258-286). UK: Cambridge University Press

[46] Hulstijn, J. H., Hollander, M., \&Greidanus, T. (1996). Incidental vocabulary learning by advanced foreign language students: The influence of marginal glosses, dictionary use, and reoccurrence of unknown words. The Modern Language Journal, 80(3), 327-339.

[47] Jacobs, G. M. (1994). What lurks in the margin: Use of vocabulary glosses as a strategy in second language reading. Issues in Applied Linguistics, 5(1), 123-136.

[48] Jenkins, J. R., Stein, M. L., \&Wysocki, K. (1984). Learning vocabulary through reading. American Educational Research Journal, 21(4), 767-787.

[49] Joe, A. (1995). Text-based tasks and incidental vocabulary learning. Second Language Research, 11(2), 149-158.

[50] Judson, E. (2006). How teachers integrate technology and their beliefs about learning: Is there a connection? .Journal of Technology and Teacher Education, 14(3), 581-597.

[51] Kalyuga, S., Chandler, P., \&Sweller, J. (1999). Managing split-attention and redundancy in multimedia instruction. Applied Cognitive Psychology, 13(4), 351-372.

[52] Kelly, B. (1986). The Effectiveness of Videodisc Instruction in Teaching Fractions to Learning-Disabled and Remedial High School Students. Journal of Special Education Technology, 8(2), 5-17.

[53] Kennedy, G. (2003). Amplifier collocations in the British National Corpus: Implications for English language teaching. Tesol Quarterly, 37(3), 467-487.

[54] Kerka, S. (2000). Incidental Learning. Trends and Issues Alert (No. 18). New York, NY: Peter Lang.

[55] Kim, B., Park, H., \& Baek, Y. (2009). Not just fun, but serious strategies: Using meta-cognitive strategies in game-based learning. Computers \& Education, 52(4), 800-810.

[56] Knight, J. (1994). Internationalization: Elements and checkpoints (Vol. 7). Canada: Canadian Bureau for International Education Research.

[57] Ko, M. H. (1995). Glossing in incidental and intentional learning of foreign language vocabulary and reading. University of Hawaii Working Papers in ESL, 13, 49-94.

[58] Kohl, H. (1981). A book of puzzlements, play and invention with language. New York, NY: Schocken Books.

[59] Laufer, B. (1998). The development of passive and active vocabulary in a second language: Same or different? Applied linguistics, 19(2), 255-271.

[60] Laufer, B. (2005). Focus on form in second language vocabulary learning. Eurosla yearbook, 5(1), 223-250.

[61] Laufer, B., \&Hulstijn, J. (2001). Incidental vocabulary acquisition in a second language: The construct of task-induced involvement. Applied linguistics, 22(1), 1-26.

[62] Laufer, B., \& Nation, P. (1995). Vocabulary size and use: Lexical richness in L2 written production. Applied linguistics, 16(3), 307-322.

[63] Laufer, B., \&Shmueli, K. (1997). Memorizing new words: Does teaching have anything to do with it? RELC journal, 28(1), 89108.

[64] Lewis, M. (1993). The lexical approach (Vol. 1). Hove, UK: Language Teaching Publications.

[65] Lewis, M. (2000). Teaching collocation: Further developments in the lexical approach. Hove, England: Language Teaching Publications.

[66] Li, R. C., \&Topolewski, D. (2002). ZIP \& TERRY: A new attempt at designing language learning simulation. Simulation \& Gaming Journal, 33, 181-186.

[67] Marzano, Robert J., John L. Brown (2007). The Art and Science of Teaching: A Comprehensive Framework for Effective Instruction. Published by ASCD.

[68] McCarthy, M. (1990). Lang Teach Vocabulary. UK: Oxford University Press.

[69] McLaughlin, B. (1965). "Intentional" and" incidental" learning in human subjects: The role of instructions to learn and motivation. Psychological Bulletin, 63(5), 359.

[70] Meskill, C. (1990). Where in the world of English is Carmen Sandiego? Simulation and Gaming Journal, 21(4), 457-460.

[71] Milton, J., (2009). Measuring Second Language Vocabulary Acquisition. Bristol, England: Multilingual Matters.

[72] Naderi, M. (2002). English Language games for Persian speakers. Unpublished Dissertation, University of Shiraz. Shiraz, Iran.

[73] Nagy, W. E., \& Anderson, R. C. (1984). How many words are there in printed school English? Reading Research Quarterly, 23, 304-330. 
[74] Nagy, W. E., Anderson, R. C., \& Herman, P. A. (1987). Learning word meanings from context during normal reading. American Educational Research Journal, 24(2), 237-270.

[75] Nagy, W. E., Herman, P. A., \& Anderson, R. C. (1985). Learning words from context. Reading research quarterly, $233-253$.

[76] Nation, I. S. P. (1990). Teaching \& learning vocabulary. New York,NY: Newbury House

[77] Nation, I. S. P. (2001). Learning vocabulary in another language. Cambridge, UK: Cambridge University Press.

[78] Nation, P. (1998). Helping learners take control of their vocabulary learning. GRETA, 6(1), 9-18.

[79] Nation, P., \&Waring, R. (1997). Vocabulary size, text coverage and word lists. Vocabulary: Description, acquisition and pedagogy, 14, 6-19.

[80] Nattinger, J. R., \&DeCarrico, J. S. (1992). Lexical phrases and language teaching. UK: Oxford University Press.

[81] Newton, J. (1995). Task-based interaction and incidental vocabulary learning: A case study. Second Language Research, 11(2), 159-176.

[82] Nist, S. L., \&Olejnik, S. (1995). The role of context and dictionary definitions on varying levels of word knowledge. Reading Research Quarterly, 24, 172-193.

[83] Oyen, A., Bebko, J. (1996). The effects of computer games and lesson context on children's mnemonics strategies. Journal of Experimental Child Psychology, 62, 173-189.

[84] Palmberg, R. (1987). On lexical inferencing and the young foreign-language learner. System, 15(1), 69-76.

[85] Paribakht, T. S., \&Wesche, M. (1999). Reading and "incidental" L2 vocabulary acquisition. Studies in Second Language Acquisition, 21(02), 195-224.

[86] Pellicer-Sánchez, A., \& Schmitt, N. (2010). Incidental vocabulary acquisition from an authentic novel: Do Things Fall Apart. Reading in a Foreign Language, 22(1), 31-55.

[87] Pigada, M., \& Schmitt, N. (2006). Vocabulary acquisition from extensive reading: A case study. Reading in a Foreign Language, 18(1), 1-28.

[88] Postman, L. (1964). Short-term memory and incidental learning. Categories of human learning, 24, 145-201.

[89] Prince, P. (1996). Second language vocabulary learning: The role of context versus translations as a function of proficiency. The Modern Language Journal, 80(4), 478-493.

[90] Pulido, D. (2004). The relationship between text comprehension and second language incidental vocabulary acquisition: A matter of topic familiarity? Language Learning, 54(3), 469-523.

[91] Pulido, D. (2007). The effects of topic familiarity and passage sight vocabulary on L2 lexical inferencing and retention through reading. Applied Linguistics, 28(1), 66-86.

[92] Purushotma, R. (2005). Commentary: You're not studying, you're just. Language Learning \& Technology, 9(1), 80-96.

[93] Qian, D. D. (1999). Assessing the roles of depth and breadth of vocabulary knowledge in reading comprehension. Canadian Modern Language Review/La revue canadienne des languesvivantes, 56(2), 282-308.

[94] Qian, D.D. (2002). Investigating the relationship between vocabulary knowledge and academic reading performance: an assessment perspective. Language Learning 52(3), 513-536.

[95] Read, J. (1993). The development of a new measure of L2 vocabulary knowledge. Language testing, 10(3), 355-371.

[96] Read, J. (2000). Assessing vocabulary. UK: Cambridge University Press

[97] Read, J. (2004). Research in teaching vocabulary. Annual Review of Applied Linguistics, 24(1), 146-161.

[98] Read, J., \& Chapelle, C. A. (2001). A framework for second language vocabulary assessment. Language Testing, $18(1), 1-32$.

[99] Richards, J. C. (1976). The role of vocabulary teaching. TESOl Quarterly, 3, 77-89.

[100] Robertson, J., \& Howells, C. (2008). Computer game design: Opportunities for successful learning. Computers \& Education, 50(2), 559-578.

[101] Rollings, A., \& Adams, E. (2003). Andrew Rollings and Ernest Adams on game design. New York, NY: New Riders.

[102] Rosszell, H. R. (2007). Extensive reading and intensive vocabulary study in a Japanese university. ProQuest.

[103] Rott, S. (1999). The effect of exposure frequency on intermediate language learners' incidental vocabulary acquisition and retention through reading. Studies in Second Language Acquisition, 21(04), 589-619.

[104] Salman, Z. (2001). The effect of games on mental development of elementary school children, Unpublished Dissertation, TarbiatModares University, Tehran, Iran.

[105] Sanaoui, R. (1995). Adult learners' approaches to learning vocabulary in second languages. The Modern Language Journal, $79(1), 15-28$.

[106] Saragi, T., Nation, I. S. P., \& Meister, G. F. (1978). Vocabulary learning and reading. System, 6(2), $72-78$.

[107] Sawyer, B., \& Smith, P. (2008). Serious games taxonomy. Retrieved from http://www.dmill.com/presentations/serious-gamestaxonomy-2008.pdf on October 5, 2012.

[108] Schmidt, R. (1994). Implicit learning and the cognitive unconscious: Of artificial grammars and SLA. Implicit and explicit learning of languages, 22, 165-209.

[109] Schmitt, N. (2008). Instructed second language vocabulary learning. Language Teaching Research, 12, $329-363$.

[110] Schmitt, N. \& Carter, R. (2004). Formulaic sequences in action: An introduction. In N. Schmitt (Ed.), Formulaic sequences: Acquisition, processing, and use (pp. 1-22). Amsterdam, The Netherland: Benjamins.

[111] Segers, E., \&Verhoeven, L. (2003). Effects of vocabulary training by computer in kindergarten. Journal of Computer Assisted Learning, 19(4), 557-566.

[112] Simpsom-Vlach, R., Ellis, N.C., 2010. An academic formulas list: new methods in phraseology research. Applied Linguistics, $31(4), 487 \mathrm{e} 512$.

[113] Sinclair, J. (1991). Corpus, concordance, collocation. UK: Oxford University Press.

[114] Siyanova, A., \& Schmitt, N. (2007). Native and nonnative use of multi-word vs. one-word verbs. IRAL-International Review of Applied Linguistics in Language Teaching, 45(2), 119-139.

[115] Smith, F. (1998). The book of learning and forgetting. New York, NY: Teachers College Press.

[116] Swanborn, M. S. L., \& De Glopper, K. (2002). Impact of reading purpose on incidental word learning from context. Language Learning, 52(1), 95-117. 
[117] Swanborn, M. S., \& De Glopper, K. (1999). Incidental word learning while reading: A meta-analysis. Review of Educational Research, 69(3), 261-285.

[118] Tavakoli, M., \& Gerami, E. (2012). The Effect of Keyword and Pictorial Methods on EFL Learners' Vocabulary Learning and Retention. PortaLinguarum, 19, 299-316.

[119] Turgut, Y., \& Irgin, P. (2009). Young learners' language learning via computer games. Procedia-Social and Behavioral Sciences, 1(1), 760-764.

[120] Tuzun, H., Yilmaz-Sollu, M., Karakus, T., Inal, Y., \&Kizilkaya, G.(2008). The effects of computer games on primary school student's achievement and motivation in geography learning. Computers \& Education, 52(1), 68-78.

[121] Waring, R., \& Takaki, M. (2003). At what rate do learners learn and retain new vocabulary from reading a graded reader. Reading in a Foreign language, 15(2), 130-163.

[122] Webb, S. (2007). The effects of repetition on vocabulary knowledge. Applied Linguistics, 28(1), 46-65.

[123] Wesche, M., \& Paribakht, T. S. (1998). The influence of task in reading-based L2 vocabulary acquisition: Evidence from introspective studies. Perspectives on lexical acquisition in a second language, 18, 19-59.

[124] Wideman, H. H., Owston, R. D., Brown, C., Kushnirk, A., Ho, F., Pitts, K. C. (2007). Unpacking the potential of educational gaming: a new tool for gaming. Simulation and Gaming, 38(1), 10-30.

[125] Wilkins, D. A. (1972). Linguistics in language teaching. Cambridge, MA: MIT Press.

[126] Wolf, M. J. (Ed.). (2001). The medium of the video game. US: University of Texas Press.

[127] Wray, A. (2002). Formulaic Language and the Lexicon. UK: Cambridge University Press.

[128] Yip, F., \& Kwan, A. (2006, September 1). Online vocabulary games as a tool for teaching and learning English vocabulary. Educational Media International, 43(3), 233-249.

[129] Yoshii, M. (2006). L1 and L2 glosses: Their effects on incidental vocabulary learning. Language Learning \& Technology, 10(3), 85-101.

[130] Zahar, R., Cobb, T., \& Spada, N. (2001). Acquiring vocabulary through reading: Effects of frequency and contextual richness. Canadian Modern Language Review/La Revue canadienne des languesvivantes, 57(4), 541-572.

[131] Zimmerman, B. J. (2001). Theories of self-regulated learning and academic achievement: An overview and analysis. In B. J. Zimmerman \& D. H. Schunk (Eds.), Self-regulated learning and academic achievement: Theoretical perspectives (pp. 1-37). Mahwah, NJ: Erlbaum.

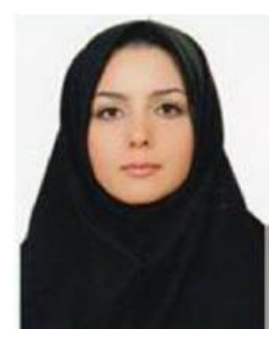

Samira Ghanbaran was born in Iran, Isfahan on September 21st, 1986. She earned her diploma in Physics and Mathematics at Isfahan University of Technology High School, Isfahan, Iran on June 19th, 2004. She continued her studies in BA in English Literature, English department of the University of Isfahan, Isfahan, Iran. Degree was earned on September 21st, 2008. She got her MA in English Teaching, English department of the University of Isfahan, Isfahan, Iran. She has been teaching IELTS and TOEFL preparation courses to advanced EFL learners for four years. She is interested in Discourse Analysis, Testing Theories, Sociolinguistics, Pragmatics and all related courses in second language learning.

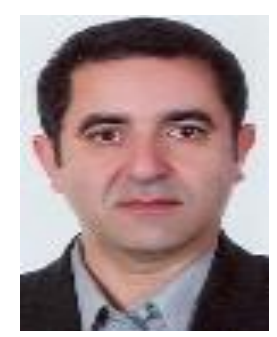

Saeed Ketabi has a Ph.D. in Applied Linguistics from the University of Cambridge, England and is currently teaching various ELT courses at the Faculty of Foreign Languages of the University of Isfahan. He has published more than forty articles and 15 books. 